\title{
Eksterminacja przyrody w Lesie Rzuchowskim
}

Mikołaj Smykowski

TEKSTY DRUGIE 2017, NR 2, S. 61-85

DOI: $10.18318 /$ td.2017.2.4

\section{Wprowadzenie}

Celem artykułu jest pokazanie, że Zagłada, która dla człowieka stała się doświadczeniem granicznym, również dla środowiska naturalnego okazała się wydarzeniem przełomowym. Regenerację $\mathrm{i}$ adaptację do zmian powstałych wskutek krótkotrwałej, acz intensywnej eksterminacji krajobrazu', można zatem porównać do ludzkiego przepracowywania traumy. Prowadzone w tym tekście rozważania umiejscawiam w ramach krytyki ekologicznej, środowiskowej historii Holokaustu i zintegrowanych badań nad dziedzictwem. Inspiracje czerpię zaś z ontologii relacyjnych ${ }^{2}$, które umożliwiają przekroczenie binarnego

1 Określenia "eksterminacja krajobrazu" używam za Mariuszem Kistowskim, Eksterminacja krajobrazu Polski jako skutek wadliwej transformacji społeczno-gospodarczej państwa, w: Studia krajobrazowe a ginące krajobrazy, red. D. Chylińska, J. Lach, Instytut Geografii i Rozwoju Regionalnego UWr, Wrocław 2010.

Ontologie relacyjne (relational ontologies) czy też ontologie płaskie (flat ontologies) to podejścia mające na celu odkrywanie symetrycznych relacji między podmiotami wchodzącymi w skład wielogatunkowych (ludzko-nie-ludzkich) kolektywów. Przykładami ontologii
Mikołaj Smykowski

(1988) - etnograf, antropolog. Doktorant Wydziału Historycznego Uniwersytetu im. A. Mickiewicza w Poznaniu. Przygotowuje pracę doktorską zatytułowaną „Ekologie Zagłady".

Autor artykułów i rozdziałów w pracach zbiorowych dotyczących materialności Zagłady i krajobrazów byłych obozów Stutthof w Sztutowie i Kulmhof w Chełmnie nad Nerem.

Stypendysta Ośrodka Badań nad Kulturami Pamięci przy Uniwersytecie Jagiellońskim. Kontakt: mikolaj.smykowski@gmail.com 
ujęcia relacji między tym, co kulturowe i naturalne, materialne i niematerialne oraz ludzkie i nie-ludzkie. Bazę empiryczną moich rozważań stanowią badania terenów byłego Obozu Zagłady w Chełmnie nad Nerem (Kulmhof), a zwłaszcza obszar obozu zlokalizowany w Lesie Rzuchowskim (Waldlager Kulmhof). Przedmiotem analizy będzie relacja niemieckiego nadleśniczego Heinza Maya, zatrudnionego przez personel obozowy w celu zamaskowania procesu zbrodni. Istotne z perspektywy podejmowanego problemu będzie prześledzenie działań potwierdzających logikę myślenia ekologicznego w ramach aranżacji terenów Lasu Rzuchowskiego (zarówno w trakcie trwania Zagłady, jak i po jej zakończeniu) lub jej zaprzeczających. Badania wykażą, że powojenna polityka zarządzania materialną pamięcią Zagłady w Chełmnie nad Nerem splata się z jednoczesnym sprawowaniem kontroli nad przyrodą i regulowaniem jej wegetacji.

\section{Topografie Zagłady}

Kiedy w 1978 roku Claude Lanzmann prowadził w Lesie Rzuchowskim wywiad z ocalałym z Obozu Zagłady w Chełmnie nad Nerem Szymonem Srebrnikiem, na taśmie filmowej została zarejestrowana wypowiedź, która wyznacza sposób rozumienia tego, w jaki sposób przyroda zakrywa i przekształca ${ }^{3}$ tereny byłych obozów koncentracyjnych i zagłady: Es ist schwer zu erkennen, aber es war hier. Srebrnik, który w Chełmnie pojawia się po raz pierwszy od czasów istnienia obozu, nie rozpoznaje polany w Lesie Rzuchowskim takiej, jak ją zapamiętał. Przestała ona być bowiem obszarem, gdzie dominującą rolę odgrywa człowiek ${ }^{4}$.

Roma Sendyka stawia pytanie o swoistość miejsc, które za Lanzmannem nazywa nie-miejscami pamięci (w przeciwieństwie do Pierre'a Nory, który ujemny kwantyfikator lokował przed słowem pamięć - miejsca nie-pamięci)

relacyjnych są: na gruncie badań społecznych teoria aktora-sieci (actor-network theory) Bruno Latoura, w archeologii teoria splątania (entanglement) lana Hoddera oraz ontologia wzajemnych powiązań (connectivity ontology) zaproponowana przez Rodneya Harrisona, odnosząca się do badań nad dziedzictwem. W nurcie postantropocentrycznej krytyki filozofii relacji ludzi i nie-ludzi uprawianej przez Donnę Haraway horyzontalny model ontologiczny uwidacznia się natomiast w pojęciu "noturokultury".

3 R. Sendyka Pryzma - zrozumieć nie-miejsce pamięci, w: Inne przestrzenie, inne miejsca, red. D. Czaja, Czarne, Wołowiec 2013, s. 278.

4 "Trudno rozpoznać, ale to było tutaj”, C. Lanzmann Shoah, 1985, rozdział 4, 00:07:05. 
lub, parafrazując Georges'a Didi-Hubermana, miejscamimimo wszystko 5 . W obu przypadkach kluczowym zagadnieniem staje się sposób, w jaki zarastające dziką roślinnością miejsca masowych mordów pozostają pozornie ukryte, będąc jednocześnie wyraźnym dla lokalnych społeczności akcentem w topografii ich okolic. Autorka wskazuje także - powołując się na wywiad z Lanzmannem, w którym nazywa on swój film „topograficznym” - ścisłą zależność procedur nazistowskich zbrodni od miejsc, w jakich były one dokonywane. Współcześni badacze terenów byłych obozów koncentracyjnych i Zagłady, a także innych miejsc masowej eksterminacji, wpisujący się w paradygmat historii środowiskowej, często odwołują się właśnie do topografii, wskazując i opisując punkty krajobrazu naturalnego, w których dochodziło w czasie Zagłady do zbrodni: Andrew Charlesworth używa pojęcia topografii ludobójstwa (topography of genocide) ${ }^{\mathbf{6}}$, Jessica Rapson pisze o topografii cierpienia (topography of suffering) ${ }^{7}$. Z kolei brytyjska archeolożka Caroline Sturdy Colls posługuje się pojęciem topografii okrucieństwa (topography of atrocity) ${ }^{\mathbf{8}}$; podobnie czyni też amerykańska antropolożka Sharon Macdonald ${ }^{9}$. „Umiejscowienie” jest szczególnie istotne z perspektywy geografii relacyjnej (relational geography), której jednym z celów badawczych jest rekonstrukcja topologicznych odwzorowań terenu. Kładzie ona nacisk głównie na obrazowanie lokalnych sieci relacji poszczególnych czynników naturalnych i antropogenicznych spajających miejsca i konceptualizuje powiązania między nimi ${ }^{10}$. Jest to pokrewne ujęcie z współczesnymi koncepcjami humanistycznymi i społecznymi operującymi metaforami sieci i splątania w celu opisu zjawisk zachodzących w obrębie „tego, co społeczne”, by posłużyć się pojęciem Bruno Latoura.

5 R. Sendyka Pryzma - zrozumieć nie-miejsce pamięci..., s. 279-28o.

6 A. Charlesworth The Topography of Genocide, w: The Historiography of the Holocaust, ed. D. Stone, Palgrave Macmillan, Basingstoke 2004, s. 216-252.

7 J. Rapson Topographies of Suffering. Buchenwald, Babi Jar, Lidice, Berghahn, New York 2015.

8 C.S. Colls Holocaust Archaeologies. Approaches and Future Directions, Springer, New York 2015, s. 9. Warto wspomnieć, że artykuł Colls zatytułowany $O$ tym, co minęło, lecz nie zostało zapomniane: Badania archeologiczne na terenie byłego obozu Zagłady w Treblince, został opublikowany w 2012 roku, w 8 numerze rocznika "Zagłada Żydów. Studia i materiały”. Autorka przedstawia w nim wyniki nieinwazyjnych badań archeologicznych, które prowadziła w ramach Holocaust Landscapes Project.

Sh. MacDonald Difficult Heritage: Negotiating the Nazi past in Nurnberg and beyond, Routledge, London 2009. 
Badania nad historią Lasu Rzuchowskiego wpisują się w szerszy kontekst badań prowadzonych w miejscach masowych mordów, których na terenie Europy Środkowo-Wschodniej jest znacznie więcej"11. Wskazują na to chociażby Timothy Snyder w książce Skrwawione ziemie. Europa między Hitlerem a Stalinem ${ }^{12}$ oraz Martin Pollack w eseju Skażone krajobrazy ${ }^{13}$. Drugi z autorów szczególnie wnikliwie przygląda się procesom celowej rekultywacji lub spontanicznej sukcesji wtórnej roślinności rodzimej w opisywanych przez niego sielskich krajobrazach, obarczonych niedostrzegalną na pierwszy rzut oka, skrywaną w koronach drzew i zaroślach niskopiennej flory podszytu traumą masowych mordów:

Właśnie to mam na myśli, gdy mówię o skażonych krajobrazach. To krajobrazy będące miejscem masowych mordów, dokonywanych jednak w ukryciu, z dala od ludzi, często w ścisłej tajemnicy. Gdzie sprawcy po masakrze dokładali wszelkich starań, by zatrzeć ślady. Niewygodni świadkowie byli likwidowani, doły, do których wrzucano zmarłych, były zasypywane, wyrównywane, w wielu wypadkach znowu zazieleniane, starannie obsadzane krzewami i drzewami, żeby pozwolić zniknąć masowym grobom. ${ }^{14}$

Pisząc o skażonych krajobrazach (Kontaminierte Landschaften), Pollack ma na myśli zarówno miejsca związane z działaniami Einsatzgruppen na terenach leśnych pogranicza polsko-ukraińskiego i polsko-białoruskiego (Ponary, Babi Yar), jak i miejsca wpisujące się w zbrodniczą działalność NKWD wobec ludności lokalnej i przesiedlonej podczas wojny z terenów wschodniej Polski (Katyń, Kuropaty, Charków, Miednoje). Opisywane przez niego krajobrazy - skontaminowane zdeponowanymi w ziemi szczątkami ludzkimi - porośnięte bujną roślinnością, niepokoją swoją pozorną idyllicznością. „Skażone krajobrazy są wszędzie [...]. Listę takich miejsc można by bez trudu wydłużyć" - pisze Pollack ${ }^{15}$; wydłużyć o wszystkie te miejsca, które nie doczekały się powojennego upamiętnienia, a funkcjonują do dziś, tabuizowane przez

11

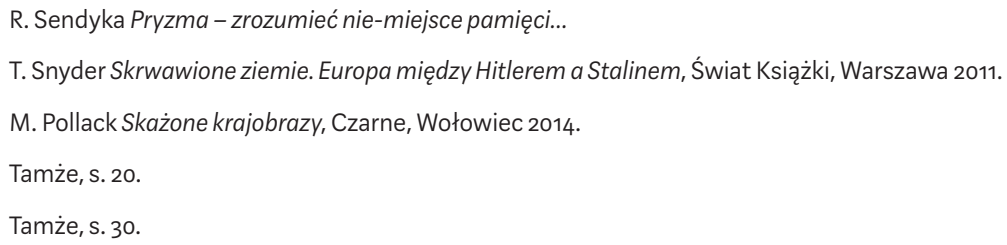


lokalną społeczność, jako przeklęte, łączone ze śmiercią i katastrofąa ${ }^{16}$. Jednym z przykładów tego typu rozumienia krajobrazu jest chociażby rozległy las Sosenki, niedaleko miejscowości Równe - stolicy ukraińskiego rejonu rówieńskiego. Jeffrey Burds w książce Holocaust in Rovno. The Massacre in Sosenki Forest, November 1941 opisuje mord na 23 ooo Ukraińców żydowskiego pochodzenia rozstrzelanych na terenach bagnistego olsu w pobliżu wioski Równe. Burds, powołując się na R. Cliftona Spargo, piszącego o miejscach przemocy (sites of violence), zauważa - podobnie jak Pollack - kluczową rolę przyrody, która w obliczu społecznej niepamięci mordu inkorporuje przemoc i staje się jej jednoczesnym, choć nie zawsze i nie dla wszystkich czytelnym, unaocznieniem i potwierdzeniem ${ }^{17}$.

Ze względu na specyfikę masowych zbrodni dokonywanych w ukryciu, bardzo często pod osłoną gęstej roślinności, uważam, że pojęcie „krajobrazu”, znacznie lepiej niż pojęcie „miejsca”, pozwala śledzić oddziaływanie między podmiotami pochodzenia naturalnego i antropogenicznego w przestrzeniach poobozowych ${ }^{18}$. Jak pokażę w dalszej części tekstu, możliwość realizacji procedur Zagłady była zależna nie tylko od technologicznych zdolności i organizacyjnej sprawności oprawców, lecz także od otoczenia przyrodniczego i lokalnej topografii, co wiązało się z możliwościami przystosowania terenów zielonych pod przyszły obóz zagłady.

\section{Ekologie Zagłady}

Postulat zrewidowania opozycji natura/kultura widoczny jest w nowych studiach nad materialnością i dziedzictwem. Nawołując do integralnej analizy dziedzictwa kulturowego i przyrodniczego, Rodney Harrison wskazuje, że idea kartezjańskiego oddzielenia natury i kultury symbolizującego także dalej idące podziały na to, co materialne i niematerialne, praktyczne i teoretyczne, ucieleśnione i pozostające domeną umysłu, jest obecnie nie do obronienia ${ }^{19}$. Dla

16 R. Sendyka Pryzma - zrozumieć nie-miejsce pamięci..., s. 281.

J. Burds Holocaust in Rovno. The Massacre at Sosenki Forest, November 1941, Palgrave Macmillan, New York 2013, s. 92-93.

W tej kwestii podążam za radą Jessiki Rapson, która podkreśla, że: „podczas gdy «miejsca» sugerują niezmienność «krajobrazowi» przypisywać można zdolność do przeobrażania się". Zob. J. Rapson Topographies of Suffering..., s. 9.

19 Prowadzący badania antropologiczne w australijskich społecznościach tubylczych, Harrison opiera swoje obserwacje na pogłębionych studiach ukazujących współdefiniowanie się obu 
brytyjskiego archeologa dziedzictwo nie jest obiektywizacją (objectification) historii rozwoju adaptacyjnych zdolności człowieka do środowiska, lecz wyłania się jako „dialog heterogenicznych ludzko-nie-ludzkich aktorów, zaangażowanych w proces zachowywania przeszłości w teraźniejszości, tworzących ukierunkowany na przyszłość asamblaż"20. Warto podkreślić, że w asamblażu tym relacje między ludzkimi i nie-ludzkimi podmiotami układają się nie wertykalnie, lecz transwersalnie. Harrison postuluje ponadto, by myśleć w kategoriach temporalnej ciągłości między przeszłością, teraźniejszością i przyszłością oraz poszukiwać odpowiedzi na pytania dotyczące ekologicznej łączności (ecological connectivity) między elementami, które często ujmuje się w kategoriach dychotomicznych ${ }^{21}$. Podobnie czynią nowi materialiści, otwarci na paradoksy wynikające z tradycyjnych ujęć, trawersujący między naturą i kulturą w aktywnym poszukiwaniu nowych teorii wyjaśniania ${ }^{22}$.

Z kolei historyk Timo Myllyntaus pisze, że względem tradycyjnych ujęć historycznych w nowej historii środowiskowej miejsce natury znacząco się zmienia: z tła wydarzeń staje się bohaterem pierwszoplanowym ${ }^{23}$. Podczas gdy klasyczne prace dotyczyły głównie tego, jak człowiek przekształcał naturę na własne potrzeby w ramach praktyk adaptacyjnych, obecnie coraz większą wagę przykłada się do studiów nad tym, jaką cenę ponosimy za jej dewastację $e^{24}$. Myllyntaus zauważa także, że coraz istotniejsze staje się myślenie w kategoriach ekosystemów.

kategorii, które zaskakująco zazębiają się, szczególnie jeśli chodzi o wykorzystywanie naturalnych zasobów spajających życie ekonomiczne, społeczne i kulturowe. Zob. R. Harrison Beyond "Natural" and "Cultural" Heritage: Toward an Ontological Politics of Heritage in the Age of Anthropocene, "Heritage \& Society" 2015 Vol. 8, s. 27.

R. Harrison Beyond "Natural" and "Cultural" Heritage..., s. 28.

Tamże, s. 29.

R. Dolphijn, I. van der Tuin New materialism: Interviews \& Cartographies, "Open Humanities Press" 2013, s. 86.

Zdaniem fińskiego badacza istnieje pięć cech dystynktywnych, dzięki którym współczesna humanistyka może zrehabilitować przyrodę $w$ dyskursie naukowym, w którym od dłuższego czasu dominował antropocentryzm: konieczność studiów ewolucyjnych w kategoriach braudelowskiej „historii długiego trwania”; badania w skali mikro - odrębne studia przypadków pozwalające na porównywanie problemów środowiskowych w skali globalnej; podejście multidyscyplinarne; perspektywa temporalna; deantropocentryzacja postrzegania przeszłości. T. Myllyntaus Environment in Explaining History: Restoring Humans as Part of Nature, w: Encountering the Past in Nature. Essays in environmental history, ed. by T. Myylyntaus, M. Saikku, Ohio University Press, Athens, $\mathrm{OH}$ 2001, s. 145-150.

4 T. Myllyntaus Environment in Explaining History..., s. 144. 
Z postulatem tym zgadza się Richard C. Foltz, który w artykule Czy przyroda jest sprawcza w rozumieniu historycznym? twierdzi, że:

[historycy] w swoich pracach wciąż koncentrują się niemal wyłącznie na interakcjach i połączeniach między ludźmi. A przecież powinniśmy pamiętać, że ludzie wchodzą nie tylko w interakcje ze sobą nawzajem, lecz również - zawsze i wszędzie - ze światem nie-ludzi. Wszelkie działania człowieka zachodzą w kontekście ekosystemów, które w różnym miejscu i czasie mają na nie najróżniejszy wpływ..$^{25}$

Oddzielanie od siebie ekosystemów i systemów społecznych jest zdaniem Foltza niebezpieczne: poza tym, że oferuje jedynie fragmentaryczną wiedzę o świecie, wskazuje także, że to "fatalne rozłączenie podmiotów" (ludzkich i nie-ludzkich) może okazać się w przyszłości przyczynkiem nagłego i globalnego załamania ekologicznego ${ }^{26}$.

W nieodległej przeszłości jednym z takich załamań była niewątpliwie Zagłada europejskich Żydów związana z istotnymi przeobrażeniami (czy w niektórych przypadkach nawet eksterminacją) krajobrazu naturalnego ${ }^{27}$. W tym sensie środowiskowa historia Holokaustu manifestuje ekologiczny aspekt historii ratowniczej. Zbalansowanie narcystycznie antropocentrycznej wizji Zagłady przez emancypacyjnie ekocentryczną może stać się impulsem do budowania bardziej symetrycznych i zrównoważonych interpretacji przeszłości ${ }^{28}$. Jak pisze Ewa Domańska:

historia ratownicza przekracza perspektywę antropocentryczną, krytycznie podchodząc do kolonizatorskich i instrumentalnych form wykorzystywania przyrody, i wskazuje na jej samoistną wartość. Sceptycznie podchodzi także do rozdziału natury i kultury, podejmując takie problemy badawcze, które pokazują, jak historia ludzka przeplata się (a często nawet staje się) historią naturalną. W tym sensie historia ratownicza łączy się

R.C. Foltz Czy przyroda jest sprawcza w znaczeniu historycznym? Historia świata, historia środowiska oraz to, w jaki sposób historycy moga pomóc ocalić Ziemię, w: Teoria wiedzy o przeszłości na tle współczesnej humanistyki, red. E. Domańska, Wydawnictwo Poznańskie, Poznań 2010, s. 633.

Tamże, s. 634 .

Zob. E. Katz Nature's Healing Power, the Holocaust, and the Environmental Crisis, "J) udaism" 1997 Vol. 46, No. 181, s. 79-89. 
z nieantropocentryczną historią ekologiczną i poszukuje inkluzywnych sposobów badania i przedstawiania przeszłości, które wskazywałyby na możliwości neutralizowania prowadzącej do dewastacji środowiska [...] działalności człowieka. ${ }^{29}$

Ontologie relacyjne i metodologie uwrażliwiające na „nowe formy sprawstwa" umożliwiają poszukiwanie odpowiedzi na stawiane dotychczas przez historyków i antropologów pytania związane z ekologicznymi aspektami Zagłady. Upodmiotowienie bytów do tej pory pomijanych czy też podrzędnych (subaltern) względem ludzi, takich jak rośliny czy przedmioty, i uczynienie ich „znaczącymi innymi” (significant others) jest warunkiem sine qua non procesu powstawania ekologicznie powiązanej „naturokultury”.

\section{Eksterminacja krajobrazu}

Cytowany już Szymon Srebrnik w 2001 roku podczas wywiadu udzielonego Instytutowi Yad Vashem, mówił: „Kiedy dotarliśmy do Chełmna, starsi ludzie mówili: Co to za piękne miejsce. Będziemy tutaj szczęśliwi. Jest tu zielono, ptaki śpiewają. Prawdziwe uzdrowisko!"30. Przytoczony fragment wywiadu, zamieszczony w najnowszej pracy pod redakcją Łucji Pawlickiej-Nowak, zawierającej szereg niepublikowanych dotąd relacji świadków funkcjonowania Obozu Zagłady w Chełmnie nad Nerem, znajduje swoje odzwierciedlenie w nazistowskiej polityce lokowania obozów koncentracyjnych i zagłady w pozornie sielankowym otoczeniu. James E. Young w Texture of Memory pisał: „Obozy koncentracyjne bardzo często zakładane były nieopodal zachwycająco pięknych, ustronnych wsi - jako ironiczna perwersja sielanki, jak często wspominają ocaleni"31.

Instrumentalne posługiwanie się przyrodą przez nazistów - celowe kamuflowanie miejsca zbrodni i restrykcyjna dbałość o niedostępność terenów

E. Domańska Historia ratownicza "Teksty Drugie" 2014 nr 5, s. 20. W tym kontekście badania środowiskowe mają wiele wspólnego ze studiami postkolonialnymi i postludobójczymi. T. Myllyntaus Environment in Explaining History..., s. 159. Ł. Pawlicka-Nowak Świadectwa Zagłady. Obóz w Chełmnie nad Nerem, Getto wiejskie Czachulec, Muzeum II Wojny Światowej, Gdańsk 2015, S. 29.

E.J. Young The texture of memory: Holocaust Memorials and Meaning, Yale University Press 1993, s. 316. Na problem ten wskazuje także Jacek Małczyński w artykule poświęconym posthumanistycznemu i ekokrytycznemu ujęciu krajobrazowego otoczenia miejsc zagłady. Zob. J. Małczyński Krajobrazy Zagłady w perspektywie posthumanistycznej „Historyka” t. 45, s. 55-77. 
obozów dla osób postronnych, czyniły z roślinności je okalającej rodzaj buforu oddzielającego społeczność lokalną od miejsca zbrodni. Dodatkowym czynnikiem, który zdaniem komendantów obozowych miał tuszować ślady zbrodni, było obsiewanie mogił trawą lub obsadzanie ich rodzimą roślinnością, m.in. drzewami i krzewami. Dokładną chronologię etapów przekształcania Lasu Rzuchowskiego pod obóz zagłady przedstawia w swoich wspomnieniach niemiecki nadleśniczy Heinz $\mathrm{May}^{32}$. Niesamowite świadectwo Maya pokazuje proces eksterminacji więźniów Chełmna i sprzężoną z nim konsekwentną dewastację lokalnego ekosystemu leśnego, jest swoistym przykładem myślenia ekologicznego w ramach bardzo świadomego i „zagęszczonego" opisu mechanizmu Zagłady.

Późną jesienią 1941 roku, w drodze z Chełmna nad Nerem do Koła, Heinz May usłyszał po raz pierwszy od zaprzyjaźnionego urzędnika (Kreisleitera powiatu Koło), choć nie dosłownie, o planowanej eksterminacji Żydów z terenów Kraju Warty:

jechałem w towarzystwie Landrata Kreisleitera Bechta z Chełmna do Koła. Gdy przejeżdżaliśmy przez las, powiedział Becht wskazując ręką w stronę rewiru 77: „Pańskie drzewa będą wkrótce lepiej rosły”. Kiedy spojrzałem na niego pytająco, odpowiedział, że Żydzi dają dobrą mierzwę [chodzi o odchody, nawóz - M.S.]. Chciałem się dowiedzieć czegoś bliższego. Becht był jednak bardzo tajemniczy i zmienił temat rozmowy. ${ }^{33}$

Tego samego (lub następnego) dnia, podczas rozmowy telefonicznej z leśniczym Steagmeierem, May dowiaduje się o przejęciu przez oddziały SS terenów obszaru lasu w rejonie działki 77 oraz działek sąsiednich - wszystkich należących do Steagmeiera.

zapytałem leśniczego Steagmeiera telefonicznie, co się dzieje w jego leśnictwie. Odpowiedział, że rewir 77 został przez żandarmerię zupełnie otoczony. [...] [znajdujące się tam - M.S.] posterunki miały polecenie

Fragment wspomnień Heinza Maya (rozdział III: Wielki mord na Żydach) w opracowaniu Karola Mariana Pospieszalskiego: Niemiecki nadleśniczy o zagładzie Żydów w Chełmnie nad Nerem, „Przegląd Zachodni" $1962 \mathrm{nr}$ 3. Rozdział ten został także opublikowany w aneksie wydanej dwa lata później książki Edwarda Serwańskiego Obóz Zagłady w Chełmnie nad Nerem, Wydawnictwo Poznańskie, Poznań 1964 - z której cytuję kolejne fragmenty. 
strzelania do każdego człowieka, który zbliżył się do rewiru 77. [...] Rewir ten obejmował gęsty las świerkowy i młode 12-15 letnie drzewa. ${ }^{34}$

Działania Waldkommando Kulmhof na terenie „rewiru 77” były całkowicie utajnione i prowadzono je bez zgody i wiedzy nadleśniczego Hainza Maya. Ścisła tajemnica państwowa, którą objęty był proces powstawania Obozu Leśnego, potwierdziła się wraz z brakiem odzewu w sprawie zażaleń Maya odnośnie do zagarnięcia terenów leśnych przez żandarmerię SS, wysyłanych przez niego do krajowego nadleśnictwa w Poznaniu.

Na początku 1942 roku Heinz May zostaje nagle, w trybie pilnym wezwany do krajowego urzędu leśnictwa, do Reichsstattehaltera SS Oberführera dra Mehlhorna. Oto jak wspomina to spotkanie:

Udałem się do niego. SS Oberführer dr Mehlhorn powiedział mi, że przecież wiem, co się dzieje w Chełmnie. Równocześnie zwrócił mi jeszcze uwagę na obowiązek zachowania ścisłej tajemnicy, gdyż w przeciwnym razie nie uniknąłbym kary śmierci. Potem powiedział do mnie, że kierownik komando specjalnego SS Sturmbannfuhrer Bothmann ma nawiązać ze mną kontakt, bo chodzi o zasadzenie drzew na grobach na rewirze 77 . Mehlhorn powiedział do mnie, że groby te trzeba za wszelką cenę dobrze zamaskować. ${ }^{35}$

Choć dokładnej daty spotkania Maya z Mehlhornem nie udało się ustalić, najprawdopodobniej zbiegła się ona z datą ucieczki dwóch więźniów, Szlamy Winera i Mordechaja Podchlebnika, której konsekwencją mogło stać się przeniesienie ówczesnego komendanta obozu Kulmhof Herberta Lange do pracy w Głównym Urzędzie Bezpieczeństwa Rzeszy (RSHA). W tym właśnie czasie stanowisko komendanta obozu przejmuje SS Hauptsturmführer Hans Johann Bothmann, który dostaje z Berlina rozkaz o konieczności zamaskowania terenu obozu leśnego - w szczególności masowych mogił. Winer i Podchlebnik, którzy ukrywali się wtedy jeszcze na terenie powiatu kolskiego, opowiadali okolicznym mieszkańcom o tym, co dzieje się z Żydami przetrzymywanymi w dawnym pałacu w Chełmnie. Kamuflaż w postaci ogrodzenia i nasadzeń był zatem koniecznym krokiem w zaprzeczaniu plotkom szybko rozchodzącym się wśród lokalnej społeczności .

Tamże, s. 74 . 
SS Oberführer dr Mehlhorn wydał Mayowi oficjalny rozkaz ogrodzenia całego terenu rewiru 77 płotem, wskazując, że „maskowanie jest rzeczą bardzo pilną i musi być zaraz przeprowadzone"36. Po kilku dniach SS Sturmbannführer Bothmann zjawia się u Heinza Maya, aby omówić kwestię maskowania. May wspomina ich wspólny pobyt w rewirze 77, który został już w sporej części przekształcony w obóz zagłady:

Jadę z Bothmannem do rewiru 77. Przerażony wkraczam po raz pierwszy na to straszliwe miejsce. Na polanie, która została przez wyrąb rozszerzona, widzę najpierw grób mniej więcej $200 \mathrm{~m}$ długości i $5 \mathrm{~m}$ szerokości. Grób jest pokryty ziemią na wysokość ok. $2 \mathrm{~m}$. Nieco dalej znajduje się taki sam grób o długości ok. $50 \mathrm{~m}$. Na innej polanie położonej ok. $50 \mathrm{~m}$ w bok znajduje się grób długości $150 \mathrm{~m}$. Ten grób był na 3/4 długości zasypany. Drugi koniec był jeszcze otwarty. Nie odważyłem się tam pójść i rzucić okiem. ${ }^{37}$

May podczas pobytu w Lesie Rzuchowskim widzi po raz pierwszy, w jaki sposób traktowane są zwłoki Żydów wydobywane z mobilnych komór gazowych; Bothmann natomiast tłumaczy, w jaki sposób są one deponowane w zbiorowych mogiłach: „zwłoki układa się dokładnie, warstwami; w przeciwnym razie grób pomieściłby za mało"38. W przeciwieństwie do procesu wykopu mogił podejmowanego zimą (za pomocą kilofów i szpadli), na przedwiośniu 1942 roku praca nad wykopami została zmechanizowana - na miejscu pojawiły się koparki z napędem motorowym oraz specjalna taśma transportująca ziemię służącą do zakopywania zapełnionych ciałami dołów.

Niedługo po wizycie w Obozie Leśnym, wstrząśnięty May zamawia sadzonki drzew. W swoim pamiętniku odnotowuje: „zamówiłem w hurtowni

36 Tamże.

Tamże, s. 79. Uważa się, że podczas pierwszego spotkania Heinza Maya z Hansem Bothmannem May przyglądał się dołom wykopanym przez Szlamę Weinera i Mordechaja Podchlebnika (dół później nazwany został Mogiłą 1) oraz pierwszym wykopom prowadzonym przy użyciu koparki (Mogiła 2, tzw. „Włocławska”). Zob. także: Ł. Pawlicka-Nowak Badania archeologiczne na terenie Ośrodka Zagłady w Chełmnie nad Nerem, w: Ośrodek Zagłady Żydów w Chełmnie nad Nerem w świetle najnowszych badań. Materiały z sesji naukowej, red. Ł. Pawlicka-Nowak, Konin 2004, s. 21-22; P. Montague Chełmno. Pierwszy nazistowski obóz zagłady, Czarne, Wołowiec 2014 , S. 185 .

Tamże. 
nasiennej większą ilość nasion jałowca ${ }^{39}$, aby to miejsce obsiać. Między jałowiec miały być posadzone świerki i brzozy"40.

O tym, że proces dewastacji lokalnego ekosystemu był jednoznacznie sprzężony z procesem eksterminacji więźniów ośrodka zagłady Kulmhof, mogą świadczyć dalsze fragmenty pamiętnika Maya dotyczące eksperymentów związanych z utylizacją zakopanych ciał. Hans Bothmann w porozumieniu z Paulem Blobelem ${ }^{41}$ początkowo stosowali do tego celu bomby termitowe ${ }^{42}$, jednak, jak wskazuje w swojej książce Patrick Montague, metoda ta była dalece nieskuteczna, ponieważ strzępy ciał utkwiły w koronach drzew, a spora część przyległego do mogiły lasu stanęła w płomieniach ${ }^{\mathbf{4 3}}$. May pisze o tym w swoich wspomnieniach:

Pewnego dnia zjawił się Bothmann w leśnictwie i powiedział mi, że otrzymał od swych zwierzchników polecenia spalenia wszystkich zwłok. Część grobów już kazał odsłonić i próbuje spalać zwłoki bombami termitowymi. Teraz chce spróbować zrobić to samo przy pomocy drewna opałowego i zażądał wielkiej ilości. Przy spalaniu przy pomocy bomb termitowych wybuchł w lesie pożar, podczas którego spłonęła część gąszczu otaczającego groby. Zwęglonych drzew nie wolno było usunąć, gdyż w przeciwnym razie pole grobów stałoby się od szosy widoczne. ${ }^{44}$

39 Tłumacz książki Patricka Montague - Tomasz S. Gałązka - prawdopodobnie nie sięgnął do wspomnień Maya przetłumaczonych i opracowanych przez Pospieszalskiego (zob. K.M. Pospieszalski: Niemiecki nadleśniczy o zagładzie Żydów...) - stąd istnieją różnice translatorskie m.in. w nazywaniu gatunków roślin obsadzanych na grobach: u Pospieszalskiego - jałowiec; u Gałązki - kolcolist.

E. Serwański, Obóz Zagłady..., s. 80.

41 Standartenführer Paul Blobel był odpowiedzialny za realizację operacji Barbarossa - dowodził Einsatzkommando 4A i odpowiadał m.in. za zbrodnie w miejscowości Babi Yar na Ukrainie. Przez otoczenie Adolfa Hitlera uważany był za eksperta w zacieraniu śladów zbrodni dokonywanych w ramach Akcji 1005. Zadaniem, które w Chełmnie nad Nerem powierzył mu Heinrich Müller, było stworzenie infrastruktury mającej służyć utylizacji zwłok zamordowanych w mobilnych komorach gazowych. P. Montague Chełmno. Pierwszy nazistowski obóz..., s. 186-187.

Termit to łatwopalna mieszanka glinu oraz tlenku żelaza, używana do produkcji bomb, których główną zaletą jest brakgłośnej eksplozji. Materiał wybuchowy ma z założenia implodować wewnątrz danego obszaru, wytwarzając wysoką temperaturę, która topi znajdujące się w pobliżu obiekty.

P. Montague Chełmno. Pierwszy nazistowski obóz..., s. 187.

E. Serwański Obóz Zagłady.., s. 81. 
W konsekwencji podjęto decyzję o utworzeniu stosów całopalnych, później zaś o wzniesieniu dwóch krematoriów wyposażonych w wysokie kominy, znacznie sprawniej odprowadzające spaliny. May zobowiązany rozkazem Bothmanna podjął się w porozumieniu z krajowym urzędem leśnictwa dostarczenia materiału opałowego. W tym celu za zgodą urzędu zmuszony był przystąpić do wyrębu okolicznych lasów:

Kazałem najpierw przetrzebić wszystkie do tego nadające się partie lasu i w wyniku tego dostarczyłem wielkie ilości konarów i chrustu gałęzi. To jednak nie wystarczyło. Musiałem dać drewno twarde. Zużycie stało się w końcu tak wielkie, że przeszedłem do trzebieży w starszych rocznikach. Wszystko to wskazywało na to, że najwyższe władze przywiązują wielką wagę do szybkiego przeprowadzenia tej akcji, gdyż zwłoki palono dniem i nocą. ${ }^{45}$

\section{Figuracje przyrody}

Szczegółowe wspomnienia Maya, przede wszystkim przedstawiona w nich nieodłączna obecność lasu, każe zastanowić się nad tym, w jaki sposób eksterminacja przyrody była sprzężona z procedurami Zagłady społeczności żydowskiej w Chełmnie i jakie role przyjmowała w ich realizacji.

Jeden z wierszy Jerzego Ficowskiego piszącego o krajobrazach Zagłady - Milczenie ziemi, zamieszczony w tomie Odczytanie popiołów, w niezwykle uchwytny sposób opisuje relację roślinności i jej dewastacji z cierpieniem ludności Żydowskiej ginącej podczas Zagłady. Podążając za liryczną intuicją autora (mimo że nie pisał on wprost o krajobrazie Chełmna nad Nerem), można by zapytać, na ile przyroda porastająca masowe mogiły, w których do dziś spoczywają szczątki około 200 tys. zamordowanych w drodze do Lasu Rzuchowskiego Żydów z Kraju Warty (Warthegau) stała się niemym świadkiem Holokaustu. Ficowski pisze:

Krzyk nie rozsadza słojów drewna, nie rozdziera ziemia murawy, nie zrywa z siebie płacht macierzanki [...]

I nie odzywają się słowem 
ani liściem, ani piaskiem

pożarci przez korzenie sosen. ${ }^{46}$

Wiersze Ficowskiego, stanowiące mikrostudium roślinnej niemocy świadczenia o wydarzeniach Holokaustu, stawiają przyrodę w niekorzystnym świetle. Niemożność dania świadectwa jest tutaj niejednoznaczna: czy drzewa i macierzanka nie chcą tego zrobić, ponieważ nie potrafią, czy też dlatego, że czują się współwinne wydarzeń, których następnie współdoświadczyły? Tak ukazana przyroda wprowadza znaczące zaburzenie w rozumieniu klasycznego Hilbergowskiego podziału na sprawcę, świadka i ofiarę Zagłady ${ }^{47}$.

Uznanie przyrody za (eko)świadka zostało zaproponowane i szerzej opisane w pracach Jacka Małczyńskiego ${ }^{48}$. Autor wskazuje tropy w myśleniu o przyrodzie jako o świadku w nurcie krytyki postantropocentrycznej (Latour, Braidotti, Haraway), łącząc je z rozważaniami Giorgio Agambena, którego definicję świadka w rozumieniu trzecioosobowym (testis) można także odnieść do rozważań Dominicka LaCapry dotyczących świadków pośrednich (secondary witnesses) ${ }^{49}$. Kiedy figuracją świadka idealnego (superstes) jest postać muzutmana, który świadczyć nie może, ponieważ widział proces Zagłady do samego końca, a zatem nie żyje - należy poszukiwać możliwości świadczenia gdzie indziej - np. w bytach nie-ludzkich, takich jak obiekty przyrody ożywionej.W takim ujęciu (elko)świadel ${ }^{50}$ jest jednocześnie dowodem popełnionej zbrodni.

Określenie przyrody jako (współ)sprawcy niesie ze sobą pewne trudności wynikające z nieprzekładalności językowej pewnych pojęć epistemicznych. W języku angielskim na określenie słowa „sprawca” używa się zwrotu perpetrator - odnosi się ono do bytu, najczęściej osoby, która popełniła jakiś czyn, zazwyczaj karalny. Z drugiej strony angielskie słowo agent oznacza (szczególnie w kontekście badań Bruno Latoura nad kategorią „sprawczości”, gdzie jego spolszczonym synonimem jest „aktant”) byt inicjujący jakieś zdarzenia, np. reakcję chemiczną. W humanistyce nieantropocentrycznej studia nad sprawczością materii

46 J. Ficowski Milczenie ziemi, w: Odczytanie popiołów, Iskry, Warszawa 1988, s. 29.

47 Por. R. Hilberg Sprawcy, Ofiary, Świadkowie. Zagłada Żydów, 1933-1945, przeł. J. Giebułtowski, Warszawa 2007.

Zob. m.in. J. Małczyński Drzewa „Żywe pomniki" w Muzeum - Miejscu Pamięci w Bełżcu, "Teksty Drugie" $2009 \mathrm{nr} 1 / 2$. Por. D. LaCapra History and Memory After Auschwitz, Cornell University Press, Ithaca 1998.

\footnotetext{
Pojęciem ekoświadka posługuje się również Ewa Domańska, zob. Historia ratownicza..., s. 20.
} 
nieorganicznej (przedmiotów) mają już dość długą tradycję; warto zatem odnieść się do rozważań amerykańskiego antropologa Alfreda Gella. W książce Art and Agency twierdzi on, że ludzkie działania zobiektywizowane w postaci materialnej mogą być uznawane za sprawców pośrednich (secondary agents) - za uprzedmiotowione sposoby użycia władzy lub chęci jej użycia ${ }^{51}$ : „obiektywizacje w postaci artefaktów pokazują jak sprawczość objawia się i realizuje przez proliferację fragmentu pierwotnej intencji sprawcy w jego wtórnej materialnej formie" $^{\prime \prime 2}$. A zatem krajobraz obozowy jako wynik jego aranżacji (przystosowania do pełnienia funkcji masowej eksterminacji) staje się przedłużeniem sprawczości tych, którzy za eksterminację odpowiadają. Tym samym krajobraz jest sprawczy, chociażby w procesie maskowania miejsca zbrodni. W takim ujęciu otoczenie przyrodnicze, usytuowanie przestrzenne oraz infrastruktura tworzą sieć działających podmiotów, w obrębie której trudno dokonać jednoznacznego podziału na artefakty i ekofakty. Jest to kolejny powód, by w myśleniu o krajobrazie poobozowym posłużyć się antydualistyczną, relacyjną perspektywą badawczą.

Przyroda w czasie Zagłady stawała się także ofiarą. Takie ujęcie przyrody najwyraźniej uwypukla współzależność wielogatunkowego kolektywu ofiar Zagłady w Chełmnie. Jeżeli przyjąć, zgodnie z hasłem badawczym środowiskowej historii Holokaustu, że ludobójstwo pociągnęło za sobą daleko idące ekobójstwo, nie można zaprzeczyć stwierdzeniu, że nie tylko w wyniku działań eksterminacyjnych (masowe groby, chemikalia, gazy spalinowe, krematoria), ale także przygotowawczych (karczowanie lasów, wzmożona wycinka związana z deficytem drewna opalającego krematoria i stosy całopalne) przyroda cierpiała wraz z człowiekiem. Efektem tego cierpienia były, i są do dzisiaj, mniej lub bardziej trwałe zmiany środowiskowe (przetrzebiony drzewostan, zanieczyszczenie powietrza, kontaminacja gleb i wód prochami ofiar).

Przyroda przyjmowała również niejednokrotnie rolę schronienia, pomagając uciekinierom z obozów koncentracyjnych i zagłady. Wspomina o tym Jeffrey Burds, opisując topografię podmokłych, gęstych puszczy rozciągających się na Ukrainie ${ }^{53}$. Podobne ujęcie możemy odnaleźć w tekście Tima Cole'a poświęconym kompleksom leśnym okalającym getta i obozy koncentracyjne w Polsce oraz na Ukrainie i Białorusi - to w nich ukrywali

A. Gell Art and Agency: An Anthropological Theory, Clarendon, Oxford 1998, s. 21.

52

Tamże, s. 22.

53

J. Burds Holocaust in Rovno... 
się uciekinierzy, by w odpowiednim czasie przystąpić do leśnych oddziałów partyzanckich. Punktem wyjścia w jego rozważaniach jest fragment świadectwa Shelyi Polishchuk, która jednoznacznie wskazuje, że przyroda pomagała uciekinierom: drzewa stawały się zbawcami maskującymi kryjówki, leśne runo dostarczało pożywienia, a padający śnieg lub deszcz zacierał ślady ucieczek $^{54}$. Z Obozu Zagłady w Chełmnie nad Nerem w pierwszym okresie jego funkcjonowania (1941-1943) uratowało się jedynie trzech więźniów - Abram Rój, Szlama Winer oraz Mordechaj Podchlebnik - oraz czterech w drugim okresie (1944-1945) - Szymon Srebrnik, Mieczysław Żurawski, Jerachmiel Widawski i Icchak Justmann. Ich ucieczki nie byłyby możliwe, gdyby nie lasy porastające tereny powiatu kolskiego ${ }^{55}$.

Multiplikacja i interferencja ról, jakie przyroda Lasu Rzuchowskiego przyjmowała w trakcie Zagłady, każe postawić tezę, że jest ona nie tylko tłem przeszłych dramatycznych wydarzeń, lecz ich integralną częścią. Działania eksterminacyjne odcisnęły bowiem silne piętno zarówno na lokalnym systemie społecznym, jak i na ekosystemie. $Z$ tego powodu uważam, że nie powinna być traktowana jako osobny, podrzędny byt, lecz raczej jako element szerszej sieci ekologicznych powiązań, bez którego przeprowadzenie, a także późniejsze przepracowanie Zagłady w Chełmnie jest niemożliwe.

\section{Krajobraz pośmiertny}

Martin Pollack w Skażonych krajobrazach pisał:

[sprawcy] chcą by doły i pogrzebane w nich ciała zniknęły. Na zawsze. Często wymaga to iście ogrodniczej wiedzy. Które drzewa i krzewy najlepiej nadają się do zasadzenia na zasypanych rowach wypełnionych zwłokami i które na tyle szybko rosną, żeby zatrzeć przypadkowe ślady? Oczywiście trzeba, w miarę możliwości, wybierać naturalne dla tego środowiska rośliny, ponieważ inne mogłyby dopiero naprawdę ściągnąć uwagę na to miejsce. ${ }^{56}$

54 T. Cole "The Nature Was Helping Us": Forests, Trees, and Environmental Histories of Holocaust, „Environmental History" October 2014 Vol. 19, s. 666-671.

Zob. P. Montague Chełmno. Pierwszy nazistowski obóz..., rozdz. Ucieczki, s. 207-227 oraz rozdz. Ocaleni, s. 341-344. 
Proces maskowania śladów zbrodni przez zarząd obozu w Chełmnie, działający za pośrednictwem lokalnego nadleśniczego, odpowiada tendencjom nazistów do ukrywania masowych mogil, wtapiania ich w naturalne otoczenie. Jednak na przekór intencjom oprawców krajobraz pośmiertny, by posłużyć się jednym z poetyckich określeń Ficowskiego, tętni życiem ${ }^{57}$. Radykalna akcja ekobójcza, towarzysząca eksterminacji ludności żydowskiej w Chełmnie, obróciła się ostatecznie przeciwko pierwotnym założeniom zarządu obozu, by za pomocą sadzonek drzew i nasion roślin niskopiennych ukryć miejsce zalegania szczątków ludzkich. Jacek Małczyński, pisząc o podobnym zjawisku na terenie Obozu Zagłady w Bełżcu, zauważa: „paradoksalnie bowiem, gest oprawcy, który dla zamaskowania zbrodni sadzi w tym miejscu rękami ofiar las, stanowić może gest upamiętnienia"58 - w tym sensie rośliny jako (eko) świadkowie stają się „żywymi pomnikami”. Nie wszystkie one na terenie Lasu Rzuchowskiego przetrwały do dzisiaj. Przeważająca część nasadzeń z czasów funkcjonowania obozu została wykarczowana wraz z procesem odkopywania zwłok pogrzebanych w masowych mogiłach w celu ich kremacji i powtórnego pochówku - ten makabryczny proceder opisuje cytowany Heinz May.

W pierwszym etapie powojennych prac Głównej Komisji Badania Zbrodni Niemieckich w Polsce uczestniczyła Zofia Nałkowska. W zbiorze Medaliony zamieściła napisane po wizycie w Chełmnie nad Nerem opowiadanie zatytułowane Człowiek jest mocny, częściowo bazujące na świadectwie ocalałego Mordechaja Podchlebnika, częściowo zaś na jej osobistych impresjach związanych z pobytem w Lesie Rzuchowskiem, o którym pisze: „Na rozległej polanie, w ramie niskich, ciemnych, gęsto rosnących sosen leżały smugi słabiej zarosłej niskiej trawki. Nie było na nich zielonych gałązek wrzosu, łochyń ani paproci"59. Całkiem możliwe, że opisywane przez Nałkowską „smugi” to rozkopane wiosną 1942 roku masowe mogiły, z których ekshumowane przez nazistów zwłoki czekała kremacja oraz powtórny "pochówek” w ramach wdrożenia dyrektyw Paula Blobela. Po ponownym zasypaniu prochów miejsca te nie były już ponownie obsiewane sadzonkami drzew. Niemniej

57 J. Ficowski Krajobraz pośmiertny, w: Odczytanie popiołów, Iskry, Warszawa 1988, s. 20. O witalności martwych przestrzeni i zacieraniu granic między życiem i martwotą obozów koncentracyjnych i zagłady zob. także: A. Kłos Ogród życia, ogród śmierci-dwie egzystencje w obozie. Eden kontra Auschwitz, "Narracje o Zagładzie” 2015 nr 1, s. 163-188.

58 J. Małczyński Drzewa "żywe pomniki" w Muzeum - Miejscu Pamięci w Bełżcu, "Teksty Drugie” $2009 \mathrm{nr} 1 / 2$, s. 210. 
jednak próby maskowania były jeszcze później podejmowane. Podchlebnik wspomina, że niwelacji gruntu w trakcie wycofywania się Kommando Kulmhof z Lasu Rzuchowskiego w 1945 roku towarzyszyło pokrywanie grobów i miejsc po wysadzonych polowych krematoriach darniami mchu ${ }^{60}$. Mech ten z uwagi na zbyt dużą ekspozycję polany na światło słoneczne z pewnością się nie przyjął.

„Poczerniałe blizny krajobrazu, które w swoim czasie natura odzyska, aby cykl wegetatywny mógł się domknąć"61 - obserwowane przez Nałkowską w maju 1945 roku, już podczas prac komisji zaczęły porastać bujną trawą i roślinami łąkowymi. Sędzia śledczy Władysław Bednarz, przewodniczący Komisji, tak opisuje ten proces:

Należy jeszcze zaznaczyć, że wskutek użyźniania ziemi popiołami ludzkimi - roślinność na tym pasie ziemi jest o wiele bujniejsza i o bardziej intensywnym zielonym zabarwieniu. Np. na polanie, gdzie były zasypywane popioły, od razu na pierwszy rzut oka pasy te zwracają uwagę swym odmiennym wyglądem. ${ }^{62}$

Mimo to, jeszcze przez kilkadziesiąt powojennych lat „blizny krajobrazu” miały się do końca nie zasklepić. Miejsca masowych mogił na zmianę stawały się obszarami dewastacji kolonizującej je roślinności (w ramach prac komisji śledczych, badań archeologicznych, rozkopywania mogił przez lokalną ludność, zabiegów aranżacji terenu) oraz jej rekultywacji (nasadzenia estetyzujące przestrzeń upamiętnienia). Po zakończeniu prac Głównej Komisji Badania Zbrodni Niemieckich w Polsce miejscowa ludność spontanicznie przeprowadzała doraźne akcje porządkowania terenów Lasu Rzuchowskiego. Pierwsze zorganizowane próby aranżacji zaniedbanej polany byłego Obozu Leśnego przeprowadzono w latach 1950-1956 i wiązały się one w głównej mierze z pracami porządkowymi na terenie masowych mogił ${ }^{63}$. Dopiero w latach 60.

$60 \quad$ Ł. Pawlicka-Nowak Badania archeologiczne..., s. 20.

61 Określenie zaczerpnięte z M. Addis, A. Charleswoth Memorialization and the Ecological Landscapes of Holocaust Sites: The cases of Plaszow and Auschwitz-Birkenau, "Landscape Research", vol. 27, s. 248 .

62 W. Bednarz Obóz..., s. 21.

63 Ł. Pawlicka-Nowak Dzieje upamiętnienia byłego obozu zagłady w Chełmnie nad Nerem (do 1995 r.), w: Świadkowie Chełmna mówiq̨, red. Ł. Pawlicka-Nowak, Oficyna Bibliofilów, Konin 2004 , s. 34 . 
$\mathrm{XX}$ wieku podjęto decyzję o zrealizowaniu planu zagospodarowania przestrzeni na podstawie projektu architektonicznego $0^{64}$. W tym czasie tereny Lasu Rzuchowskiego znalazły się pod opieką ówczesnego resortu leśnictwa, który w porozumieniu z Radą Ochrony Pomników Walk i Męczeństwa oraz Wydziału Kultury Urzędu Wojewódzkiego w Poznaniu wydał zgodę na realizację założeń projektowych. Przed rozpoczęciem prac nie dokonano jednak archeologicznych badań sondażowych, których przeprowadzenie uniemożliwiłoby dość niefortunne zaprojektowanie betonowej ścieżki przecinającej w połowie jedną z masowych mogił (Mogiła 1).

Cmentarzysko w lesie rzuchowskim zostało w latach 1960-64 uporządkowane według projektu przygotowanego bez jakichkolwiek badań, po prostu realizowano wizję architekta nie zastanawiając się nad skutkiem takiego działania. ${ }^{65}$

Polana w Lesie Rzuchowskim została zniwelowana przez spychacze, a ziemię zaorano leśnymi pługami, naruszając warstwę kostną znajdującą się w płytszych obszarach mogił. Podobnie dość arbitralne nasadzenia drzew i krzewów - a część z nich bezpośrednio w miejscu masowych grobów - zatarły niektóre nadziemne ślady istnienia ośrodka zagłady. Działania te w dużym stopniu przyczyniły się do trwałej destrukcji materiału dowodowego.

W latach 1962-1964 postanowiono o obmurowaniu zarysów masowych mogił, wytyczono je jednak dość nieprecyzyjnie; przykładowo, tzw. Mogiła 2 („Włocławska”) została skrócona o 45 metrów - może to wskazywać , że jej południowa część, która nie została odrestaurowana, znajduje się obecnie w obszarze ściany lasu powstałego najprawdopodobniej wskutek nasadzeń wykonywanych przez Heinza Maya. Pozostałe trzy mogiły, w tym Mogiła 3 (która także częściowo znajduje się w lesie), również zostały obmurowane.

W latach 70. przeprowadzono dalsze prace ziemne - wytyczono m.in. dodatkowe ścieżki, także asfaltowe, i nasadzono kolejne krzewy dekoracyjne. Stan zagospodarowania mogił na rok 1978 widoczny jest w kadrach filmu Lanzmanna Shoah. Ocalały Szymon Srebrnik przechadza się murowanymi obrysami zbiorowej mogiły (Mogiła 4), która w drugim okresie funkcjonowania obozu stała się miejscem ostatecznego spoczynku skremowanych szczątków więźniów Chełmna. Właśnie przy tej mogile jako grabarz pracował Srebrnik.

64 Autorem projektu został inż. Zdzisław Samulczyk.

65 Ł. Pawlicka-Nowak Badanie archeologiczne..., s. 21. 
Dalsze prace nad zagospodarowaniem terenów Lasu Rzuchowskiego toczyły się pod koniec lat 8o., kiedy Muzeum Okręgowe w Koninie podjęło się przeprowadzenia pierwszych badań archeologicznych (lata 1986-1987). Prace te postępowały etapowo, ich kontynuację wznowiono w latach 1997-2002, później zaś w latach 2003-2004. Są one o tyle istotne dla omawianego problemu, że precyzyjne wytyczenie zasięgu zbiorowych mogił za pomocą metod sondażowych i fotointerpretacji zdjęć lotniczych przyczyniło się do późniejszego przesunięcia ich betonowych obrysów w ramach prac modernizacyjnych wykonywanych wczesną wiosną 2015 roku. Towarzyszyło im również wzniesienie drewnianej kładki nad betonową drogą prowadzącą na wskroś przez Mogiłę 1.W tym samym roku zasypano doły po badaniach archeologicznych, przykryte do tej pory niszczejącą pod wpływem czynników atmosferycznych agrowłókniną oraz wyremontowano ścieżki prowadzące do Ściany Pamięci.

Działania towarzyszące porządkowaniu i aranżowaniu terenów Lasu Rzuchowskiego niejednokrotnie miały inwazyjny charakter wobec regenerującej się roślinności. Można do nich zaliczyć regularną erozję ziemi towarzyszącą budowie upamiętnień mogił i badaniom archeologicznym, selektywną wycinkę drzew i krzewów czy stosowanie herbicydów na odrestaurowanych już mogiłach. Z drugiej strony podejmowano działania rekultywacyjne, których celem była restytucja krajobrazu naturalnego, odbywały się one głównie przez nasadzenia estetyzujące spacerową przestrzeń miejsca pamięci. Nietrudno zauważyć, że oba przedsięwzięcia nie przystają do siebie, a rekultywacja flory w ramach zdegradowanego ekosystemu nigdy nie będzie powrotem do stanu pierwotnego. $Z$ tego powodu zarządzanie materialnymi nośnikami pamięci o przeszłości i zarządzanie przyrodą ustanawiają w relacji do siebie nowy typ dziedzictwa o charakterze naturokultury.

\section{Uzdrawiająca moc natury}

Piękno masowych grobów było dla mnie zaskoczeniem, a nawet mnie zszokowało. To jest właśnie reifikacja ironii. Cmentarz - monument destruktywnej nienawiści wpisanej w nazistowski Holokaust - zdaje się być zadziwiająco piękny. Przepełniony bujnym, niepohamowanym rozrostem drzew i wegetacją roślin, cmentarz demonstruje potęgę Natury odnawiającej się pośrodku miejsca ludzkiej zagłady. ${ }^{66}$

66 E. Katz Nature's Healing Power..., s. 80. 
Tak Eric Katz opisuje swój pobyt w 1995 roku na Cmentarzu Żydowskim w Warszawie oraz w Treblince. Podobne wrażenie można odnieść obecnie, spacerując polanami Lasu Rzuchowskiego. Przyroda Obozu Leśnego nie napotkała od 2015 roku większych przeszkód w procesie regeneracji, jednak jej sukcesja wtórna jest regulowana, a swobodne przerastanie polan bylinami i roślinnością łąkową możliwe jest tylko w określonych miejscach: wkoło głównego założenia pomnikowego, na terenie lapidarium macew zwiezionych z rozebranych w czasie wojny i niszczejących po wojnie kirkutów powiatu oraz w przestrzeniach między małą architekturą - pojedynczymi upamiętnieniami, mogiłami i miejscami, w których znajdowały się pozostałości obozowej infrastruktury.

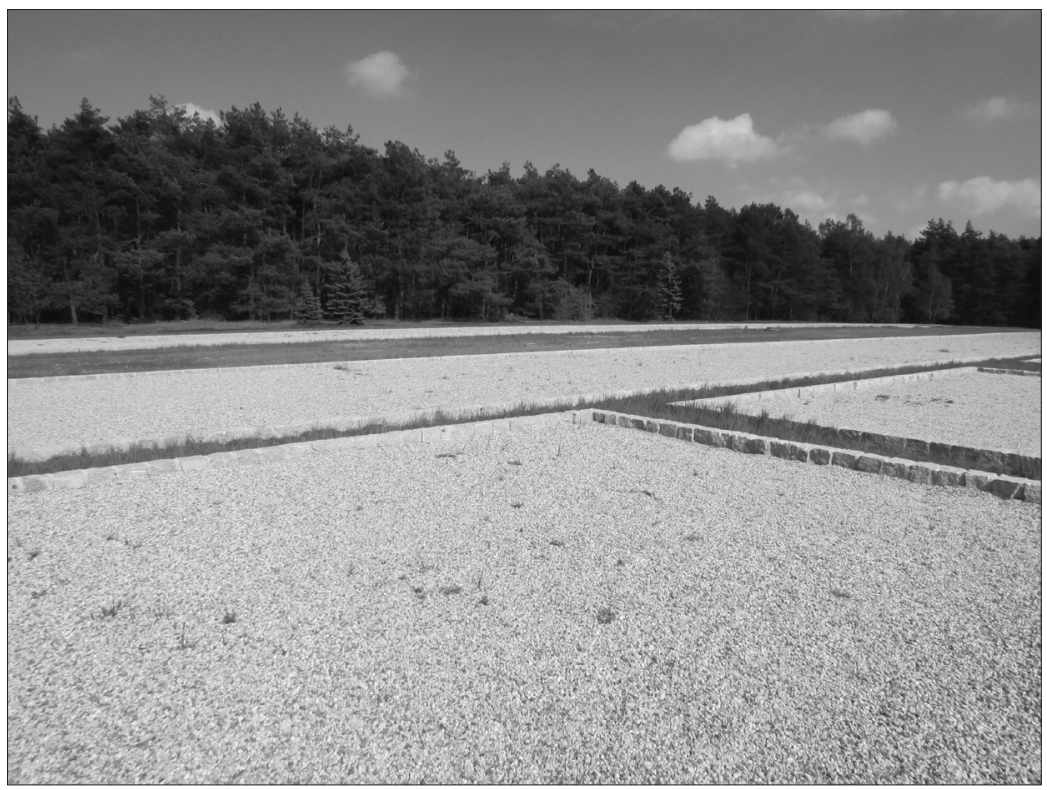

Fot. 1. Aranżacje masowych mogił na polanie Lasu Rzuchowskiego. Fot. M. Smykowski (2015)

W artykule Nature's Healing Power... Katz zauważa, że przywracanie ekologicznej równowagi ekosystemów, odtwarzanych pozornie na wzór ich pierwotnego stanu, jest przesiąknięte ideologią antropocentryczną. Naturalne ekosystemy skrzywdzone działalnością człowieka rekultywowane są tak, by zadowalać obecne oczekiwania danej populacji, chcącej osiągnąć dwa cele jednocześnie: ulżyć poczuciu winy za czyny poprzednich pokoleń, 
zwalniając siebie z odpowiedzialności za destrukcję ekosystemu naturalnego oraz zademonstrować naukową i technologiczną władzę nad naturą ${ }^{67}$. W takim ujęciu uwidacznia się złożoność krajobrazu, którego elementy przyrodnicze stają się jednocześnie kulturowymi konsekwencjami działań rekultywacyjnych:

przywrócony krajobraz ludzki jest wynikiem innego rodzaju przyczynowości niż ekosystem naturalny - ponowne pojawienie się Natury w miejscu masowej zagłady jest efektem niewymazywalnych działań człowieka. Naturalna roślinność pokrywająca masowe groby [...] nie jest tą samą roślinnością, która wyrosłaby, gdyby groby te nigdy nie zostały wykopane. $^{68}$

Wraz z drastycznym załamaniem się ekosystemu Lasu Rzuchowskiego roślinność musiała wypracować mechanizmy adaptacyjne do nowych warunków środowiskowych: zmienionego pH gleby wskutek nagromadzenia w niej pierwiastków pochodzących z dekompozycji kości i tkanek ofiar pogrzebanych w masowych mogiłach ${ }^{69}$, zwiększonej ekspozycji na światło słoneczne spowodowanej przetrzebieniem lasu, wzmożonego spływu powierzchniowego i naturalnej erozji. Spowodowały one, że tylko niektóre gatunki roślin zdolne były do kolonizacji zdewastowanych obszarów, co więcej - tylko ich wydzielonej przez człowieka części.

Oznacza to, że „praca naprawcza”, jaką wykonuje roślinność, w pewien sposób pozostaje dalej skutkiem działań człowieka, „przywrócona natura, nie jest już wcale naturą" - jak pisze Katz. Z drugiej strony natomiast „uzdrawiająca moc przyrody" objawia się w jej nieustępliwym dążeniu do zasklepienia blizn w krajobrazie. Bliznami tymi są już nie tylko efekty ekobójczej nazistowskiej polityki, lecz także wszelkie działania, które jako próby przywrócenia stanu ekosystemu sprzed Zagłady, siłą rzeczy, stają się wtórnymi działaniami skierowanymi przeciwko przyrodzie.

67 Tamże, s. 84.

68 Tamże, s. 88.

69 Więcej na temat procesu dekompozycji ludzkiego ciała i jego wpływu na jakość gleb zob. J. Żychowski Wpływ masowych grobów z lill wojnyświatowej na środowisko przyrodnicze, Wydawnictwo Naukowe AP, Kraków 2008. 


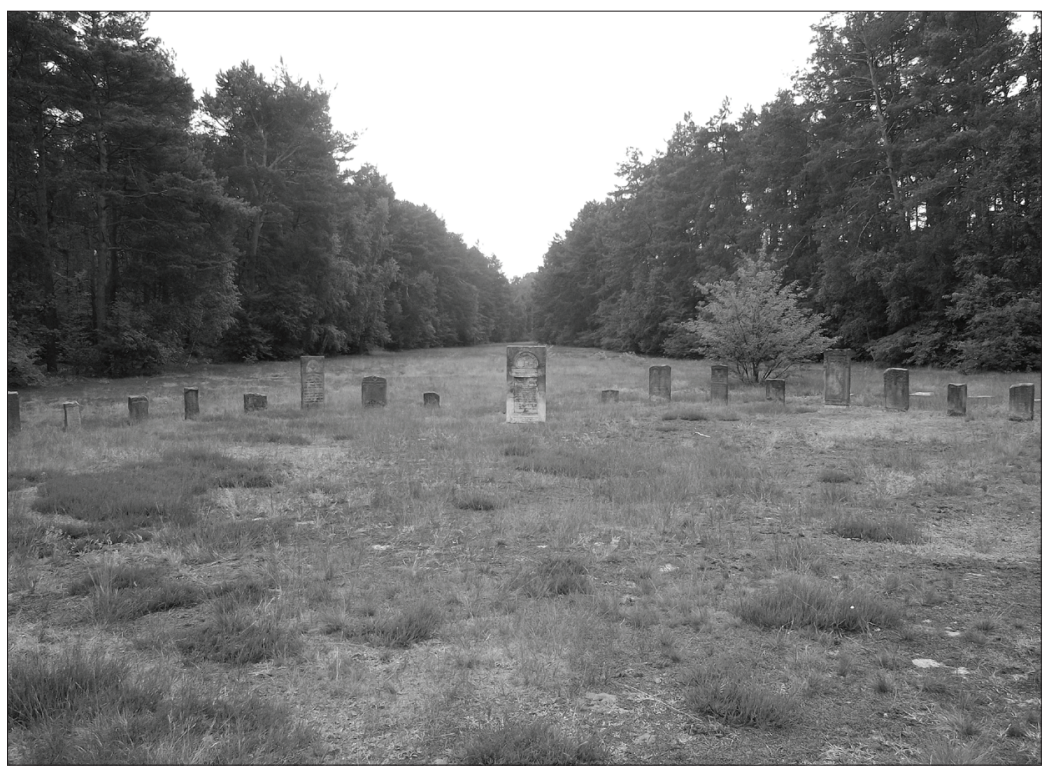

Fot.2. Lapidarium macew porośniętych wrzosem (Calluna sp.), rozchodnikiem ostrym (Sedum acre) oraz jarzębcem kosmaczkiem (Hieracium pilosella). Fot. M. Smykowski (2012)

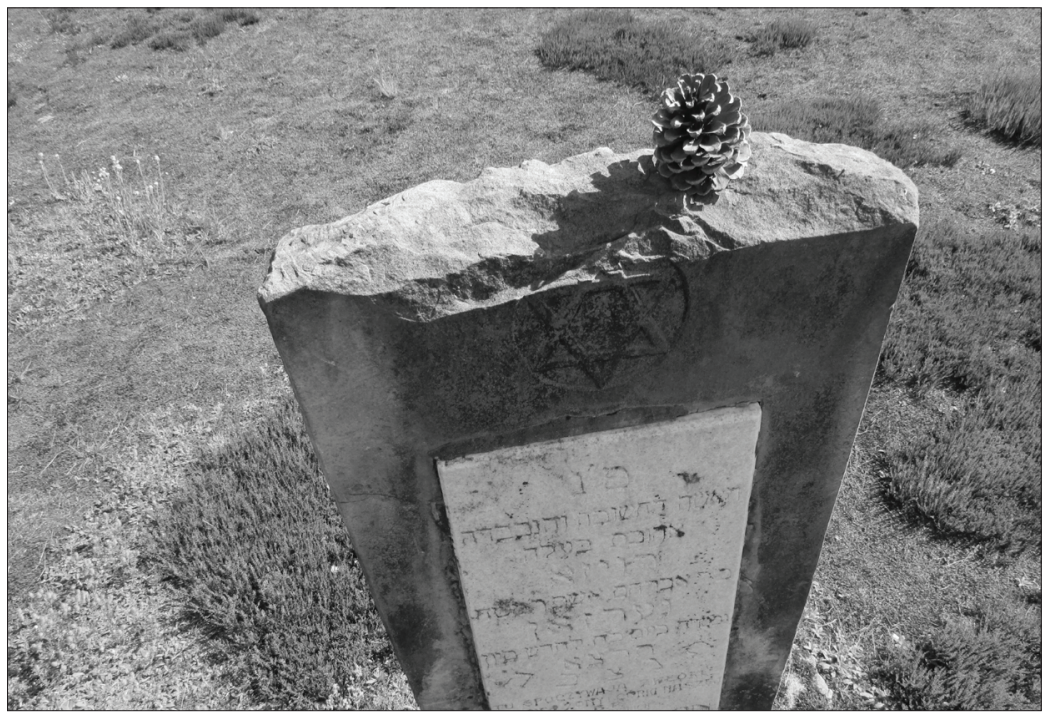

Fot. 3. Szyszka sosnowa ustawiona na jednej z macew zamiast kamienia. Fot. M. Smykowski (2016) 


\section{Zakończenie}

Współczesny krajobraz Lasu Rzuchowskiego jest efektem krzyżowania się ludzkich i nie-ludzkich działań. Zagłada stała się wydarzeniem, które zmieniło bieg jego naturalnej historii. Procesy przekształcające lokalny ekosystem leśny, które trwale wpłynęły na jego obecny stan, można podzielić na te pochodzenia antropogenicznego i te proweniencji naturalnej. Do pierwszej kategorii należy przede wszystkim zaliczyć instrumentalne posługiwanie się roślinnością w ramach maskowania zbrodni oraz jej arbitralne traktowanie podczas prób rekultywacji środowiska przyrodniczego. Druga kategoria obejmuje procesy o charakterze samoczynnym, przede wszystkim tropizmy roślinne wskazujące kierunki dalszej sukcesji. Ekologiczna zależność elementów obu kategorii spaja krajobraz, jest skutkiem ich wzajemnych, długotrwałych oddziaływań. Sprawia, że Las Rzuchowski można rozpatrywać jako ekodziedzictwo, którego kluczową właściwością jest to, że nie ukazuje jedynie procesu adaptacji człowieka do środowiska, ale także środowiska do zmian antropogenicznych. Relacyjność takiego ujęcia obnaża niedostatek dualistycznej dystynkcji między naturą i kulturą i pokazuje, że myślenie o krajobrazach Zagłady powinno polegać na integrowaniu podejść (post) humanistycznych i ekokrytycznych. Celem ich zastosowania w niniejszym tekście jest zadośćuczynienie przyrodzie jako pomijanemu w dotychczasowych studiach monograficznych podmiotowi kształtującemu poobozowy krajobraz Kulmhofu. 


\section{Abstract}

\section{Mikołaj Smykowski}

ADAM MICKIEWICZ UNIVERSITYIN POZNAŃ

Nature's Extermination in the Rzuchowski Forest

This paper examines how Nazi extermination procedures at the Chełmno Death Camp are ecologically related to the devastation of the local forest ecosystem. Smykowski explores the ecocide and subsequent attempts to restitute vegetation. His study is based on a memoire by German forester Heinz May, in charge of providing wood to fire the crematories and of concealing the mass graves with tree seedlings. The methodology and theoretical apparatus of relational ontology portray the post-Holocaust landscape as a result of interfering processes, both anthropogenic (anthropopressure, reclamation, aestheticization) and natural (secondary succession). Smykowski's approach shows the landscape of the Rzuchowski Forest as an example of an ecoheritage.

\section{Keywords}

Holocaust, ecology, extermination of nature, natureculture, ecoheritage, forest ecosystem 